\title{
Student Reported Growth: Success Story of a Master of Science in Education Learning Community Program
}

\author{
Sharon Kabes, EdD \\ Associate Professor, Department of Education \\ Southwest Minnesota State University \\ John Engstrom, EdD \\ Assistant Professor, Department of Education \\ Southwest Minnesota State University
}

\begin{abstract}
Quantitative and qualitative data collected from students who have completed a Master of Science in Education Learning Community Program support the effectiveness of the learning community model in facilitating professional growth and transformation. Instructors model constructivist theory. Peer review, collaboration, and reflective analysis of theory and practice are essential

components of the model. The program facilitates growth as educators build their understanding about teaching and learning, transfer their ideas and processes into the classroom, and take an active leadership role in promoting change in classrooms, school, and larger community.
\end{abstract}

The Master of Science in Education Learning Community Program at a Midwestern university has been designed to meet the professional development needs of educators. Since 1996, over 2000 graduates have reported and demonstrated transformational growth in their thinking about learning, in their teaching, and in their leadership. The master's of science was designed to be delivered in a non-traditional manner in off-campus cohorts, or, more specifically, learning communities. Data collected from students who have completed the program support the effectiveness of the learning community model. The program promotes teacher growth and transformation based on inquiry, classroom application, and critical reflection.

Current research on teaching and learning, and best practices are modeled. In addition, the master's of science program is aligned with professional development standards established by the National Board for Professional Teaching Standards (NBPTS) and the university Leadership Standard. The faculty work collaboratively to shape educational experiences that engage educators in critical dialogues and analysis of educational theory and practice. Collaboration and peer review are essential components of the learning experiences. Students participate with the same group of peers and the same faculty facilitators for the entire twoyear program. Each learning community meets one weekend per month at a locally accessible site. Learning communities have been located in several states.

\section{Learning Community Model}

The learning community described in this paper differs from traditional models in several ways. A team of two university professors provides leadership in the learning community over the course of the program and oversees the organization and delivery of coursework. This structure is designed to foster elements of an effective learning community which include:

- A safe learning environment supporting risk taking, mutual respect, and critical reflection

- Constructivist format in which the learner investigates and reframes understanding 
- Collaborative learning and peer review where colleagues share and receive feedback and support from permanent cohort groups.

- Readings, experiences, and activities which are spiraled over a twoyear program to build depth in understanding

- Transformational learning resulting in the revision of a learner's perspective and understanding of self

- Transferability of new learning to professional practice

- Inclusion of outside experts in content or process as necessary

Traditional cohort models often offer classes that are taught by different professors or adjuncts over a time period. In these models, classes are often taught as a single entity. As a result, students may experience a lack of continuity.

In the non-traditional learning community model described in this paper, objectives from different classes are interwoven and spiraled throughout the two year period. While the primary objectives of a course are met during a term, the objectives appear again as they are spiraled over the two year course with more intense readings and experiences, and students are moved to a different depth of understanding. There is a sense of connectedness because the classes are designed to interweave themes, theory, and practice.

In addition, students are expected to implement course outcomes into their teaching, and share their results and receive feedback from their permanent cohort teams, their advisory groups, and their job-alike teams. Van der Aalsvoort and Harinck (2000), in their review of methods for studying social interactions in instruction and learning, observed that the learner's construction of knowledge results from the interdependence between social and individual processes. The role of peers in the learning process is critical. In a properly structured group learning environment, peers "encourage questioning, evaluating and constructive criticism, leading to a restructuring of knowledge and understanding" (Naylor \& Cowie, 2000, p. 93).

The facilitators model constructivist theory and work to create a safe and positive environment where students are actively

There is a sense of connectedness because the classes are designed to interweave themes, theory, and practice. engaged in inquiry, self reflection, collaborative learning, and independent learning. Peer review and collaboration are essential components of the model. The program facilitates growth as educators build their understanding about teaching and learning, transfer their ideas and processes into the classroom, and take an active leadership role in promoting change in classrooms, school, and larger community.

Themes are spiraled over the two-year experience, and theory and practice are examined in increasing depth. Books and articles are carefully selected to build student understanding and critical reflection skills. Students apply what they learn in the classroom, reflect on their implementations and critique them with their peers. In addition, students examine their own teaching skills, learning styles, multiple intelligences, personality and leadership styles and reflect on how these apply to their construction of curriculum and their teaching. As students build understanding through reflective and analytic engagement with new ideas and theories of teaching and learning, they deconstruct their thinking and understanding about teaching and learning and about their practice. They transform their thinking and their practice in the process.

Initially, students are asked to analyze their current teaching through the use of teaching surveys and videotaping of class sessions. They also are introduced to Adult Learning Style Surveys, Adult Multiple Intelligence Indicators, and Meyers Briggs Indicators to help them delineate more about their own learning, working preferences, and personality styles. Students are asked to reflect on how the information they have learned about themselves from each of these tools informs 
what they do in the classroom. Students use these initial reflections as a baseline for determining their future growth. In the second year, students examine their own leadership styles through Leadership Surveys.

Students are also exposed to bonding activities which build community and trust. They work on team building and understanding group dynamics. Each student becomes a member of a small group called an advisory team which stays together throughout the program to critique and review presentations, writing, portfolios, and action research projects. The advisory team establishes group norms expectations, and rubrics for peer evaluations. In addition, the advisory team signs off on final projects, the portfolios, and the action research projects. Students

self-assess based on growth and submit a reflection on progress which is reviewed by the advisory group prior to submitting the recommendation to the facilitators. Students are also members of a variety of homogenous and heterogeneous groups based on teaching assignment, reading materials, and research interests.

Reflection is essential to development and is the basis for transformational growth. I nitially, many students feel uncomfortable with reflective writing. The first reflections are about their own teaching and observations of classroom videos. These initial reflections are usually superficial and lack depth of thought. As students progress through the spiraled materials and discuss, evaluate, and implement their new learning in their classrooms, they begin to connect ideas, themes, and theory to practice within their reflections. Unfamiliar ideas, strategies, and practices become familiar and enter into the teaching repertoire. Students grow to become thoughtful, analytical practitioners and reflection, which once seemed unnatural and awkward, becomes a modus operandi.

Educators rarely think of themselves as leaders. One of the goals of the program is to develop an understanding of how they can become change agents in their schools and communities. Early in the process, students are introduced to the Chaos Theory of physics which explores how patterns arise out of chaos (Garmston and Wellman, 1995). Even the fluttering of a butterfly's wings can effect a change in global weather patterns.

\section{Reflection is essential to development and is the basis for transformational growth.} The butterfly wings become a metaphor for the incremental changes which occur when new teaching and learning strategies are implemented in the classroom. This, along with the study of organizational theory and dynamics, helps students understand how they can become instrumental in facilitating positive change in the classroom, the school, and the community. Students report that they are often asked questions by colleagues as a result of participating in a master's program. The changes which occur in their classrooms are shared by their own students, and others become aware of a transformation taking place. Finally, the research they conduct becomes a catalyst for pathways to change.

The portfolio is important in the learning process for it reflects the growth and transformation in the student's thinking, teaching, and learning and becomes a work in progress over the length of the program. The advisory team members assist each other in the development of the portfolios and evaluative rubrics, and offer critical reviews during the process. The final portfolio reflections epitomize the transformation in teaching and learning as students are able to connect all of their program experiences, reading, theory, and new ideas to their actual classroom practice. 


\section{Theoretical Basis for a Learning Community}

Three inter-related concepts provide the theoretical basis for this learning community model: constructivism, learning communities, and transformational learning.

\section{Constructivism}

The basis for the learning community concept lies in the theory of constructivism. According to Brooks and Brooks (1999), constructivism is a theory about knowledge and learning in which the learner is allowed to investigate and reframe understanding. Constructivism, as an epistemology, attempts to explain human learning in terms of understanding the interaction between what learners know and believe, with exposure to new events, activities, and information (AbdalHaqq, 1999). The meaning and application of knowledge are interpreted by the learner, through experience (Rainer, 1999). Constructivism is more concerned with student understanding than with accumulated facts; further, constructivism considers the role of social and cultural contexts related to learning, rather than purely cognitive learning following abstract principles (Black \& Ammon, 1992; Vygotsky, 1978; Bruner, 1996).

A constructivist learning environment utilizes experience, collaborative discourse, and reflection which, together, assist the learner to confront his or her own learning needs (Brooks \& Brooks, 1999).

Viewed within the Piagetian (1964) framework, learning takes place when the learner actively assimilates and interprets new information within the framework of existing understandings. This interaction between new information and current understandings leads to learning by forcing the learner to reformulate, or reconcile, any dissonance produced by this interaction (Black \& Ammon, 1992; Brooks \& Brooks, 1999). Vygotsky's social constructivism emphasizes the role and influence of socio-cultural forces in which learning occurs and how that context impacts learning (Vygotsky, 1978).

Dewey (1916) concluded that the primary purpose of education is to improve students' reasoning capacities and problem-solving abilities. Students' motivations to learn must arise from perceived needs originating out of problems of interest to students; students will be motivated when their learning centers on improving their abilities to solve their "real life" problems (Ornstein \& Hunkins, 1998). Learning environments in which problem solving and discovery are encouraged require teachers who facilitate student learning (Dewey).

Meaningful learning experiences are designed primarily with the learners' contexts in mind. Social constructivism, sometimes referred to as Vygotskian constructivism, emphasizes the individual's construction of knowledge through interaction with the environment (Abdal-Haqq, 1999). Although learning is an individual experience and interpretation, research indicates that people learn through interaction with others (Johnson \& Thomas, 1994). In addition, Brookfield (1995) emphasizes the role of critical reflection in the facilitation of adult learning, in order to foster the expansion of a student's capacity for lifelong learning.

\section{Learning Communities}

One of the most significant developments in higher education in recent years is the emergence of adult learners as a major constituency (Maehl, 2000). In order to accommodate this growing trend into the long-held ideal of lifelong learning, universities must create programs which acknowledge and respect non-traditional adult learners' needs and interests. These new forms of education will have to 
address the needs of professional practice while fostering reflective practitioners (Taylor, 1997).

Adult education has long emphasized group learning. Research dating back to 1946 has documented the role of groups to effect changes in behavior (French \& Bell, 2000). Yet learning in groups, or cohorts, in more formal academic programs is a new but increasingly popular option for adult learners (Nesbit, 2001). Structurally, a cohort is often defined as a group of students who enroll at the same time and complete a course of study together. However, Norris and Barnett (1994) differentiate between a cohort's structure and its purpose. While a cohort may be viewed by some as simply a delivery method or scheduling strategy, purposeful design of cohorts fosters learning and development. Purposefully designed cohorts acknowledge the role of group dynamics and principles of adult learning (Slick, 2002).

Research indicates that successful cohorts produce a sense of belonging among members, support risk taking, and foster mutual respect and critical reflection (Brooks, 1998; Lawrence, 1997). A learning environment that is safe, caring, and trusting encourages and enables learners to bring unique life experiences to the cohort. This, in turn, facilitates "learning-within-relationships" (Barlas, 2001), a function of equal participation leading to transformational learning. Kegan and Lahey's (2001) approach to adult development suggests that learning depends on one's connections with others and the context in which that learning occurs. A learning community also results in meaningful

Successful cohorts produce a sense of belonging among members, support risk taking, and foster mutual respect and critical reflection. learning and provides the necessary support

for the individuals (Slick, 2002). Current research on professional development supports the importance of collaborative and collegial learning environments where colleagues reflect on learning strategies which have been implemented in the classroom (Darling-Hammond \& Richardson, 2009). Fogarty and Pete (2009-10) report that teachers who are involved in collaborative review of implemented practices demonstrate deeper understanding, which insures transferability of new learning to professional practice.

\section{Transformational Learning}

In 1978, Mezirow proposed a new theory of adult learning. This theory originated with his research of adult women who had returned to college after an extended absence. Mezirow (2000) found that the women who had developed a critical awareness "of their beliefs and feelings about themselves and their role in society" also changed "the way they had tacitly structured their assumptions and expectations" (p.xii). This change in thinking was a "learned transformation," and the term "transformative" or "transformational" learning was born. In his analysis of Mezirow's theory, Inglis (1997) states that "transformative learning focuses on the individual and the reconstruction of the notion of self" (p.4). Transformative learning emphasizes the learning, growth, and resulting empowerment of the individual to act accordingly. The integration of new experiences with present understandings leads to a revision, or transformation, of the learner's perspective (Nesbit, 2001).

Mezirow (2000) identifies three interrelated components in the process of transformational learning: the learner's experiences, critical reflection, and rational discourse (in which the learner acts upon critical reflection). Beliefs and assumptions are questioned, allowing for the possibility of new or revised interpretations of past experiences and present realities. Only by developing an 
awareness of beliefs, values, and feelings about oneself can an individual begin the process of deep and meaningful change that constitutes learning. Changes in self-concept, examination of internalized norms, and new perspectives on past behaviors are likely to occur when adults develop the capacity for reflection (Brookfield, 1986).

In order for transformational learning to occur, critical reflection and reflective discourse are necessary. This ability to reflect on one's own, as well as others' assumptions, is inherent in the process of transformational learning (Merriam, 2004). Belenky and Stanton (2000) concluded that most adults do not have the skill to critically reflect on their thinking, nor the thinking of others. They have not had the opportunity or experience in developing this capacity.

Perhaps the most significant aspect of transformative learning is the role of critical reflection. Mezirow states that "central to this transformative process of learning is critical reflection and testing new meanings through rational discourse" (1991, p.2). Nesbit (2001) argues that the "potential of transformative learning for graduate and continuing professional education lies in its ability to encourage 'reflection-in-action,'" which leads to improved

In order for transformational learning to occur, critical reflection and reflective discourse are necessary. professional practice and greater capacity for further gains (p. 5).

It is the individual's reflection on self that drives transformative learning. Mezirow's concept of learning based on awareness of one's beliefs and assumptions requires more than the traditional "strategies... that focused on the improvement of skills and the acquisition of new techniques" (Sokol \& Cranton, 1998, p.1). This is the difference between transforming and training. The former produces an individual whose growth and learning becomes self-directed and meaningful; the latter results in an individual who is dependent on others for instruction in skill development. Brookfield (cited in Mezirow, 2000, p.125) agrees with Mezirow when he states "transformative learning cannot happen without critical reflection...."

Mezirow's theory of transformative learning has been a useful model for understanding and improving adult learning. In order to genuinely improve the teaching profession, educators must move "beyond what Freire (1970) described as the 'banking model' of teaching in which educators make deposits of information into the empty vaults of students' minds" (Sokol \& Cranton, 1998, p. 1).

\section{Learning Community Impact}

\section{Data Collection}

Data collected from students who have completed the Master of Science in Education Learning Community Program support the effectiveness of the learning community model in facilitating professional growth and transformation. The impact of the learning community experience is assessed and interpreted from data collected through survey instruments administered at various points throughout the two-year program and through student formative and summative reflections. While student learning is assessed through various projects, presentations, research, and the professional development portfolio, assessment instruments are utilized to measure the effectiveness of the learning community process in facilitating student growth and development. Several dimensions of program outcomes related to student learning have been summarized in this paper.

Upon completion of the learning community program, quantitative data in the form of surveys is collected and collated for each learning community. Three surveys are administered: a Professional Development Survey, a Facilitator Survey, and a Learning Environment Survey. Summative surveys were collected from ten 
different learning communities with three different facilitator teams. Kabes, Lamb, and Engstrom (2010) reported that survey data collected from students over a fiveyear cycle showed consistent scores of 92.5 per cent or above when rating twelve elements central to the learning community model and demonstrated the effectiveness and impact of the learning community model. The quantitative results include elements of best practices: learning environment, effective teaching strategies, research-based decision making, scaffolding, peer collaboration, learning community philosophy and professional growth, empowerment, reflective practitioner, inquiry, and transformational leader (change agent).

Qualitative data in the form of summative reflections from students are also collected. All of the summative reflections of 42 students in two first-year (2009-2010) learning communities reported growth in thinking about learning, in reflection, and in teaching. All 42 respondents described themselves as different and better teachers and learners since the start of the program. Students consistently report that they have become more reflective about their teaching. All of them describe how they have learned about themselves as learners, as thinkers and as collaborators who have grown professionally. The responses mirror those collected from students since 1998. Incremental changes have occurred and transformation of their teaching and learning is developing. This gradual transformation is observed in student formative reflections. The feedback reflects the transformation of students in their thinking and in their practice and also supports the effectiveness and impact of the learning community program.

Examples of reflective responses have been selected to demonstrate how that transformation is reported by students.

\section{Critical Reflection}

Experience in a learning community pushes students to inquire into their belief structures and philosophy, underlying values, and the actions connected to them. Readings, dialogue, and classroom applications provide experiences within which thinking and classroom practices are challenged. Initially, exposure to this inquiry-based environment leads to a period of "deconstruction" in which teachers experience dissonance in current beliefs and practice in light of newly acquired knowledge and experiences. Through consistent exposure to opportunities (individual and collective), critical reflection on practice becomes a habit of mind.

Several student responses follow that indicate the occurrence or beginnings of transformative learning. Early in their learning community experience, students responded to questions designed to elicit critical reflection on their teaching practice and their thinking as professionals. Carol, a second grade teacher, writes "I am also reflecting on my beliefs as a teacher as well as [myself] as a student. I am thinking a lot about the methods I teach in my classroom and my beliefs. I am beginning to question what I am doing and why. Through my reflections, I am beginning to develop a sense of who I am, and what I really believe." These excerpts indicate that the process of critical reflection is leading to transformative learning.

Tom, a middle school teacher, describes his development by stating “I totally wanted to take this program for a financial gain, but now I see that this program will help me become a better teacher. The books, the activities, the assignments, and the groups I work with are all making me question myself and why I do something the way I do..." Another student, Pam, who teaches kindergarten, states "I have been composing this reflection in my mind for many 
days. There are so many thoughts and 'revelations' happening...." She then describes her journey as a learner, beginning with her days as a high school student. She relates that she was always a bit embarrassed by her "love of learning" in high school and college because "it wasn't cool. For some reason, I never wanted to say it out loud." She continues by affirming her belief in herself when she says "it is a good thing to be a self-proclaimed lifelong learner!" The transformative principles of meaning, examining values, and acting are evident in her comments. In her concluding thoughts, she states that her learning is "stretching my wings... I have reached the point where I feel strongly enough that to do the best I can for my students, I have to stand up for what I know is right for them as young learners." As mentioned earlier, these educators are only several months into their graduate studies, but the beginnings of transformative learning are evident and encouraging. The data emerging from this class of educators supports Sokol and Cranton when they conclude that "adding a few more techniques to the repertoire is always of interest, but the real, and deeper, professional development involves an examination of our self as teacher, and a thorough look at what we believe - and why" (1998, p.3).

Students often report the importance of reflection and the transformation in their teaching which has happened and will continue because of that reflection and critical analysis. "The growth that I have experienced professionally over the past two years has been tremendous. This program has made me more reflective on the quality of what I do and its effect on the students and other staff in my school. I believe that I'm much more qualified, not just to teach, but to be openly critical in my attempts to provide a better environment for my students." (Student feedback)

In the settings described above, it is evident that transformative learning is a valid approach to teacher professional development. "Adult learners engaged in this process are actively questioning heretofore invisible assumptions about self, society, role, and responsibility..." (Taylor, 2000, p.159). Teachers who have experienced transformative learning as part of their professional development will not only gain a deeper understanding of the learning process, but are likely to develop a greater sense of meaning and purpose as educators (Kroth \& Boverie, 2000).

\section{Collaboration}

Collaborative problem solving leads students to share and examine their teaching practices. Breaking down teacher isolation collectively empowers teachers, and assists in developing a shared language of effective practice. Within this safe and supportive environment, teachers begin to critically examine their "teaching self," and reflect on the capacities required to perpetuate learning and growth. An important component in the students' learning community experiences, collaboration, is utilized as a means to transformative learning. Early in the graduate program, students are exposed to writings and dialogue with colleagues that challenge their assumptions about learning and teaching. This new information and new ways of thinking about education often create the conditions necessary for what Mezirow calls a "disorienting dilemma": an experience

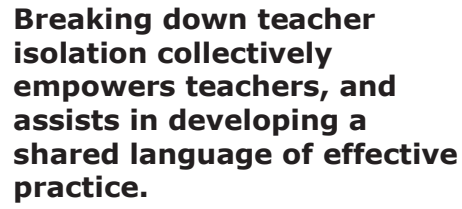

Teachers report that they have implemented the strategies and theories to which they have been exposed. This has become an integral part of their teaching repertoires. In addition, they have learned to work collaboratively to bring about changes in their classrooms, schools and communities. "This has been the best 
possible learning experience I have had in 25 years of education. I was introduced to and had an opportunity to experiment with numerous teaching strategies, learning styles, and educational opportunities. We were encouraged, advised, and challenged to become better educators. Through this program, I have gained confidence in myself, as an educator and as part of a team working to make school better for students. This program far exceeds any educational class I have taken." (Student feedback).

The dialogue with other educators contributes to the individual's personal transformation by "making public..the historical dimensions of our dilemma and confronting it as a difficulty to be worked through" (Boyd, as cited by Mezirow, 2000, p.22).

\section{Student Growth and Transformation}

Intricately tied to critical reflection and collaboration is the outcome of student growth and transformation. Schön (1983) describes the process as "reflection-in-action", in which experienced educators experience transformational learning. Educators learn to use their experiences to self-assess and revise their understanding of theory, leading to more effective practice.

The transformation which takes place in the teachers also promotes growth and understanding in the teacher as a leader. "This program has challenged, stretched and inspired me to become a leader. I can hardly put in words the direct impact this program has had on me professionally. I am stepping out and taking leadership in not only my classroom, but among my staff and district. This has given me affirmation about important decisions I make in my school. I have grown more than I would have ever imagined" (Student feedback).

Over the course of their graduate program, students consistently inquire into their belief structures through meaningful, relevant readings, activities, and problem solving. Within the structure and safety of the learning community, students progress into a deeper understanding of themselves as a learner, then as a teacher. Exposure to problems of emerging relevance leads to an increased capacity to identify problems, create responsive solutions, and to evaluate their effectiveness. This development encompasses overall professional competencies, and, specifically, personal teaching skills, and personal and professional

\author{
As part of the learning \\ community experience, \\ students examine and \\ challenge, each other's \\ thinking about teaching and \\ learning and begin the \\ transformational process in \\ which new and deeper \\ understandings replace \\ what have become \\ inadequate beliefs about \\ teaching and learning.
} leadership skills.

As part of the learning community experience, students examine and challenge, each other's thinking about teaching and learning and begin the transformational process in which new and deeper understandings replace what have become inadequate beliefs about teaching and learning. Growing as a professional educator is seen as a continuum for the future. "I never thought that a program could have such a profound impact on me as a teacher and as a person. This program is so unique-one you can't forget. I think about the changes and the impact it has on my students all of the time. In the past "traditional" courses have been good but once the book was closed the learning experience stopped. This will not be the case with this program. It's only the beginning for me" (Student feedback).

Argyris (2000) concludes that "teaching people to reason about their behavior in new and more effective ways breaks down the defenses that block 
learning" (p. 296). Experienced teachers are often revitalized as a result of their experiences. "This program has stretched me professionally and personally to heights I never thought I could attain. Furthermore, this experience has once again ignited the spark for the love of teaching I thought I had lost. The impact of what we've done in our community has reached and will continue to reach out to our classrooms, to colleagues, our families, the lives of our students, and beyond" (Student feedback).

The reflective descriptions above are representative of the types of reflections which are provided by students throughout the course of their two-year programs. The reflections support the growth and transformation which results from this learning community program.

\section{References}

Abdal-Haqq, I. (1998).

Constructivism in teacher education: Considerations for those who would link practice to theory. ERIC Digest. (ED426986)

Argyris, C. (2000). Teaching smart people how to learn. In W. French, C. Bell, \& R. Zawacki (Eds.), Organization development and transformation (pp. 295-305) Irwin: McGraw-Hill

Barlas, C. (2001). Learning-withinrelationship as context and process in adult education. Impact on transformative learning and social change agency. Paper presented at the Annual Meeting of the Adult Education Research Conference, Lansing, MI, June 1-3, 2001. (ED476040)

Belenky, M. \& Stanton, A. (2000). Inequality, development, and connected knowing. In J. Mezirow (Ed.), Learning as transformation: Critical perspectives on a theory in progress (pp. 71-102). San Francisco: Jossey-Bass.

Black, A. \& Ammon, P. (1992). A developmental-constructivist approach to teacher education. Journal of Teacher Education, 43(5), 323-335.

Brookfield, S. (1986). Understanding and facilitating adult learning. San Francisco: Jossey-Bass.
Brookfield, S. (1995). Becoming a critically reflective teacher. San Francisco: Jossey-Bass.

Brooks, J.G. \& Brooks, M.G. (1999). In search of understanding: The case for constructivist classrooms. Alexandria, VA: ASCD.

Brooks, P.A. (1998). Cohort communities in higher education. Proceedings of the $39^{\text {th }}$ Adult Education Research Conference, May 15-16, 1998. San Antonio, TX, p. 6771. (ED426247) http://www.edst. educ.ubc/ca/aerc/ 1 998/98brooks.htm

Bruner, J. (1996) The culture of education. Cambridge, MA: Harvard University Press.

Cranton, P. (1994). Self-directed and transformative instructional development. Journal of Higher Education, 65(60), Nov/Dec 1994. Ohio State University Press.

Darling-Hammond, L. \& Richardson, N. (2009). Teacher learning: What matters? Educational Leadership, 66(5), 46-55.

Dewey, J. (1916). Democracy and education. New York: McMillan.

Freire, P. ( 1970). Pedagogy of the oppressed. New York: Seabury. 
French, W. \& Bell, C. (2000). A history of organizational development. In W. French, C. Bell, \& R. Zawacki (Eds.), Organization development and transformation ( $\mathrm{pp}$. 20-42).

Garmston, R. \& Wellman, B. (1995). Adaptive schools in a quantum universe. Educational Leadership, 52 (7), 6-12.

Imel, S. (2002). Adult learning in cohort groups. Practice Application Brief no. 24. ERIC Clearinghouse on Adult, Career, and Vocational Education. (ED472604)

Inglis, T. (1997). Empowerment and emancipation. Adult Education Journal, 48 (1), 3-17.

Johnson, S.D. \& Thomas, R.G. (1994). Implications of cognitive science for instructional design in technology education. Journalof Technology Studies, 20(1), 33-45. (EJ 494218)

Kabes, S., Lamb, D. \& Engstrom, J. (2010). Graduate learning communities: Transforming educators. Journal of College Teaching and Learning, 7(5), 47-55.

Kegan, R., Lahey, L.L. (2001). How the way we talk can change the way we work: Seven languages for transformation. San Francisco: Jossey-Bass.

Kerka, S. (1997). Constructivism, workplace learning, and vocational education. ERIC Digest No. 181. (ED407573)

Kerka, S. (2003). Does adult educator professional development make a difference? Myths and realities. ERIC Clearinghouse on Adult, Career, and Vocational Education. (ED482331)

Kroth, M. \& Boverie, P. (2000). Life mission and adult learning. Adult Education Quarterly 50(2), 134-146.
Lawrence, R.L. (1997). The

interconnecting web: Adult learning cohorts as sites for collaborative learning, feminist pedagogy and experimental ways of knowing. In $38^{\text {th }}$ Annual Adult Education Research Conference Proceedings, May 16-18, Stillwater, OK, p. 179-184. (ED409460)

http://www.edst.educ.ubc.ca/aerc/19 97/97/Lawrence.html

Loucks-Horsley, S. (1995). Professional development and the learner-centered school. Theory into Practice 34 (4), 265-271.

Maehl, W.H. (2000). Lifelong learning at its best. San Francisco: JosseyBass.

Merriam, S. B. (2004). The role of cognitive development in Mezirow's transformational learning theory. Adult Education Quarterly, 55(1), 60-68.

Mezirow, J. (1991). Faded visions and fresh commitments: Adult education's social goals. A Policy Paper prepared for the AAACE. Teachers College, Columbia University. Available: http://nlu.nl.edu/ace/Resources/Doc ument. statement.html

Mezirow, J. (2000). Learning as transformation: Critical perspectives on a theory in progress. San Francisco: Jossey-Bass.

Nesbit, T. (2001). Extending graduate education to non-traditional learners. Journal of Continuing Higher Education, 49(1) 2-10.

Norris, C.J . \& Barnett, B. (1994). Cultivating a new leadership paradigm: From cohorts to communities. Paper submitted at the annual meeting of the University Council of Educational Administration, Philadelphia, PA. (ED387877) 
Novick, R., Grimstad, J. (1999). Actual schools, possible practices. New directions in professional development. Northwest Regional Educational Lab. (ED 429980)

Nuthall, G. (2004). Relating classroom teaching to student learning: A critical analysis of why research has failed to bridge the theory-practice gap. Harvard Educational Review, 74(3), 273 -306.

O'Day, J.A. (2002). Complexity, accountability, and school improvement. Harvard Educational Review, 72(3), 293-329.

Ornstein, A. C., \& Hunkins, F. P. (1998). Curriculum: Foundations, principles and issues (3rd ed.). Boston: Allyn and Bacon.

Piaget, J. (1964). Development and learning. In R. Ripple \& V. Rocksdale, (Eds.), Piaget rediscovered (pp. 719). I thaca, NY: Cornell University Press.

Sargent, T.A. (2000). Linking educators' professional development to workplace/community learning experiences. Teachnet Educational Brief, No1. (ED468218)

Schön, D.A. (1983). The reflective practitioner: How professionals think in action. New York: Basic Books.

Slick, S. (2002). Teachers are enthusiastic participants in a learning community. The Clearinghouse, 75(4), 198-201.

Smith, C. \& Hofer, J. (2002). Pathways to change: A summary of findings from NCSALL's staff development study. Focus on Basics 5(D), 1, 3-8.

Sokol, A. V., \& Cranton, P. (1998). Transformation, not training. Adult Learning, 9(3), 14-16.
Sparks, D., \& Hirsh, S. (n.d.). A National Plan for I mproving Professional Development. Staff Development Library: NSDC Strategic Plan. Retrieved November 11, 2006 from http://www.nsdc.org/library/authors/ NSDCPlan.cfm

Swafford, J.O., J ones, G.A., Thornton, C.A., Stump, S.L., \& Miller, D.R. (1999). The impact on instructional practice of a teacher change model. Journal of Research and Development in Education, 32(2), 69-81.

Taylor, E.W. (2000). Fostering transformative learning in the adult education classroom: A review of the empirical studies. Paper presented at the annual Meeting of the International Conference on Transformative Learning, New York, NY. (ED 442989)

Taylor, I. (1997). Developing learning in professional education. Bristol, PA: Open University Press.

Tom, A.R. (1999). Reinventing master's degree study for experienced teachers. Journal of Teacher Education, 50(4). 245 - 254.

Van der Aalsvoort, G.M. and Harinck, J.H. (2000). Studying Social interaction in instruction and learning: Methodological approaches and problems. In H. Cowie \& G. van der Aalsvoort (Eds.), Social interaction in learning and instruction: The meaning of discourse for the construction of knowledge. (pp. 5 -20). Oxford: Elsevier Science.

Vygotsky, L.S. (1978). Mind in Society. (M. Cole, V. John-Steiner, S. Scribner, \& E. Souberman, Eds. and Trans.). Cambridge, MA: Harvard University Press. 
Dr. Sharon E. Kabes, Associate Professor, is former Chair of the Department of Education at Southwest Minnesota State University. She is a member of the graduate faculty and has been a facilitator in the Master of Science Education Learning Community program since 2003.

Dr. John Engstrom is an Assistant Professor at Southwest Minnesota State University where he is a member of the graduate faculty. He was among the first graduates of the learning community program at SMSU; he has facilitated learning communities since 1998. 